\title{
First host record for the cleptoparasitic bee Rhathymus friesei Ducke (Hymenoptera, Apidae)
}

\author{
Hugo A. Werneck ${ }^{1}$, Gabriel A. R. Melo² \& Lucio A. O. Campos ${ }^{3}$
}

'Departamento de Entomologia, Universidade Federal de Viçosa, Av. Ph Rolfs s/n, 36570-000 Viçosa-MG, Brazil. beehugo@gmail.com
2Laboratório de Biologia Comparada de Hymenoptera, Departamento de Zoologia, Universidade Federal do Paraná, Caixa Postal 19020, 81531-980,
Curitiba, PR, Brazil. garmelo@ufpr.br. Corresponding author.
${ }^{3}$ Departamento de Biologia Geral, Universidade Federal de Viçosa, Av. Ph Rolfs s/n, 36570-000 Viçosa-MG, Brazil. lcampos@ufv.br

\begin{abstract}
First host record for the cleptoparasitic bee Rhathymus friesei Ducke (Hymenoptera, Apidae). The genus Rhathymus contains only obligatory cleptoparasitic species whose hosts belong to the genus Epicharis (Apidae, Centridini). Host information is available for only four of the 20 species of Rhathymus. In this note a new host record is added, in which the parasitism by $R$. friesei on nests of Epicharis (Epicharoides) picta is documented.
\end{abstract}

KEYWORDS. Centridini; Cleptoparasitism, Rhathymini.

RESUMO. Primeiro registro de hospedeiro para a abelha cleptoparasita Rhathymus friesei (Hymenoptera, Apidae). O gênero Rhathymus é composto apenas por cleptoparasitas obrigatórios cujos hospedeiros conhecidos pertencem todos ao gênero Epicharis (Apidae, Centridini). Para apenas quatro das 20 espécies válidas havia previamente registro de hospedeiros. O presente trabalho documenta, pela primeira vez, o parasitismo de Rhathymus friesei sobre o hospedeiro Epicharis (Epicharoides) picta.

PALAVRAS-CHAVE. Centridini; Cleptoparasitismo; Rhathymini. Rhathymus.

Rhathymus Lepeletier \& Serville, 1828, the single genus in the tribe Rhathymini, contains about 20 species restricted to the Neotropical region (Moure \& Melo 2007). All species in the tribe are obligatory cleptoparasites and only bees in the genus Epicharis Klug, 1807 (Apidae, Centridini) have been recorded as their hosts (Vesey-FitzGerald 1939; Rozen 1969, 1991; Camargo et al. 1975; Raw 1991, 1992; Hiller \& Wittmann 1994; Gaglianone 2005; Michener 2007; RochaFilho et al. 2008). The species of Epicharis are soil-nesting solitary bees, which use floral oils and exhibit a close association with the plant family Malpighiaceae (Gaglianone 2003, 2005; Rocha-Filho et al. 2008; Sigrist \& Sazima 2004; Alves-dos-Santos et al. 2007).

Little is known of the biology of Rhathymus. Available evidence indicates that the females introduce their eggs in closed brood cells of the host bees (Camargo et al. 1975), therefore corresponding to the mode of parasitism in which the female cleptoparasites invade host nests containing recently sealed brood cells and open the cell closures for egg laying (Rozen 1991, 2000, 2003). Similar to other bee groups exhibiting the same mode of parasitism, the eggs of Rhathymus are relatively large and comparable in size to the host eggs (Rozen 2003). First instars have sharp mandibles (Camargo et al. 1975) and are assumed to kill the host egg or young larva (Rozen 2000).
Host information is available for only four of the 20 species of Rhathymus. Two of them, R. bicolor Lepeletier \& Serville, 1828 and $R$. unicolor (Smith, 1854), are known to attack more than one host species (Table I). The present work constitutes the first host record for Rhathymus friesei Ducke, 1907, observed attacking nests of Epicharis (Epicharoides) picta (Smith, 1874), and therefore contributes new information to the understanding of the relationships between species of the bee tribes Rhathymini and Centridini.

Rhathymus friesei, described originally from Minas Gerais, in Brazil (Moure \& Melo 2007), is also known from São Paulo (G.A.R. Melo, unpublished). This species was synonymized by Engel et al. (2004a) under $R$. acutiventris Friese, 1906, and despite their similarity, R. friesei constitutes a separate valid species (Melo, unpublished). These two species, together with $R$. bertonii Schrottky, 1920 and additional undescribed species, constitute a distinct group within the genus. This species group was placed in a separate genus, Nannorhathymus, by Engel et al. (2004a, b), whose recognition leaves a non-monophyletic Rhathymus (G.A.R. Melo, unpublished).

The observations on $R$. friese $i$ were conducted in a nest aggregation of E. picta (20 $\left.47^{\prime} 56^{\prime \prime} \mathrm{S}, 42^{\circ} 52^{\prime} 07^{\prime \prime} \mathrm{W}\right)$ found in a site near one of the largest forest remnant, known as "Mata do Paraíso", in the municipality of Viçosa, Minas 
Gerais. The nest aggregation was studied during two consecutive seasons, from January through May, in 2010 and 2011. Vouchers of the studied bees are deposited in the Museu Regional de Entomologia, from the Departamento de Entomologia of the Universidade Federal de Viçosa (MEUFV), and in the Coleção Entomológica Pe. J. S. Moure from the Departamento de Zoologia of the Universidade Federal do Paraná, Curitiba (DZUP).

Rhathymus friesei was active in the nest aggregation between February and March, in both years of study. The cleptoparasite was repeatedly observed coming in and out of the nests of E. picta (Figs. 1-2), with up to four adult bees found in the nest aggregation at once. Females of $R$. friese $i$ would fly over the nest aggregation, usually at a height of about 30 to $50 \mathrm{~cm}$ above ground, and after selecting a given nest, they would land in front of its entrance and walk in. In most cases, the cleptoparasite would invade nests in which the host female was temporarily out. Time spent by adult $R$. friesei within the host nests, measured on five occasions, lasted 1.5 to $25 \mathrm{~min}$. In some occasions, the cleptoparasite would enter a nest in which the host female was present and would be promptly expelled by her. Also, some specimens were observed landing in the plant foliage around the nest aggregation near the end of the day $(6: 00 \mathrm{pm})$, probably in search of sleeping sites.
A total of 42 brood cells containing mature larvae were dug from the nest aggregation, 38 of them belonging to $E$. picta $(89.5 \%)$ and four to $R$. friesei $(10.5 \%)$. As in other studied species of Rhathymus (Rozen 1969; Camargo et al. 1975), and contrasting with Epicharis, larvae of $R$. friesei spin cocoons (Figs. 3-4).

Although the aggregation contained predominantly nests of E. picta, a few nests of Epicharis (Epicharoides) albofasciata Smith, 1874 were also found among them. No direct or indirect evidence was obtained indicating that $R$. friesei parasitized this other species of Epicharis. Since the adults of $E$. albofasciata are only slightly smaller than those of E. picta, it might be possible that the former species could also serve as host of $R$. friesei.

The host records currently known for Rhathymus (Table I) do not point to any clear pattern of host specificity. However, considering that the different species groups within Rhathymus vary considerably in body size, it would be expected that the smaller cleptoparasitic species, such as $R$. friesei and relatives, would be associated with the subgenera of Epicharis containing smaller body-sized species, like $E$. (Epicharoides) and E. (Epicharitides), and perhaps E. (Cyphepicharis). The new host record here documented between $R$. friesei and E. picta corroborates this expected pattern.
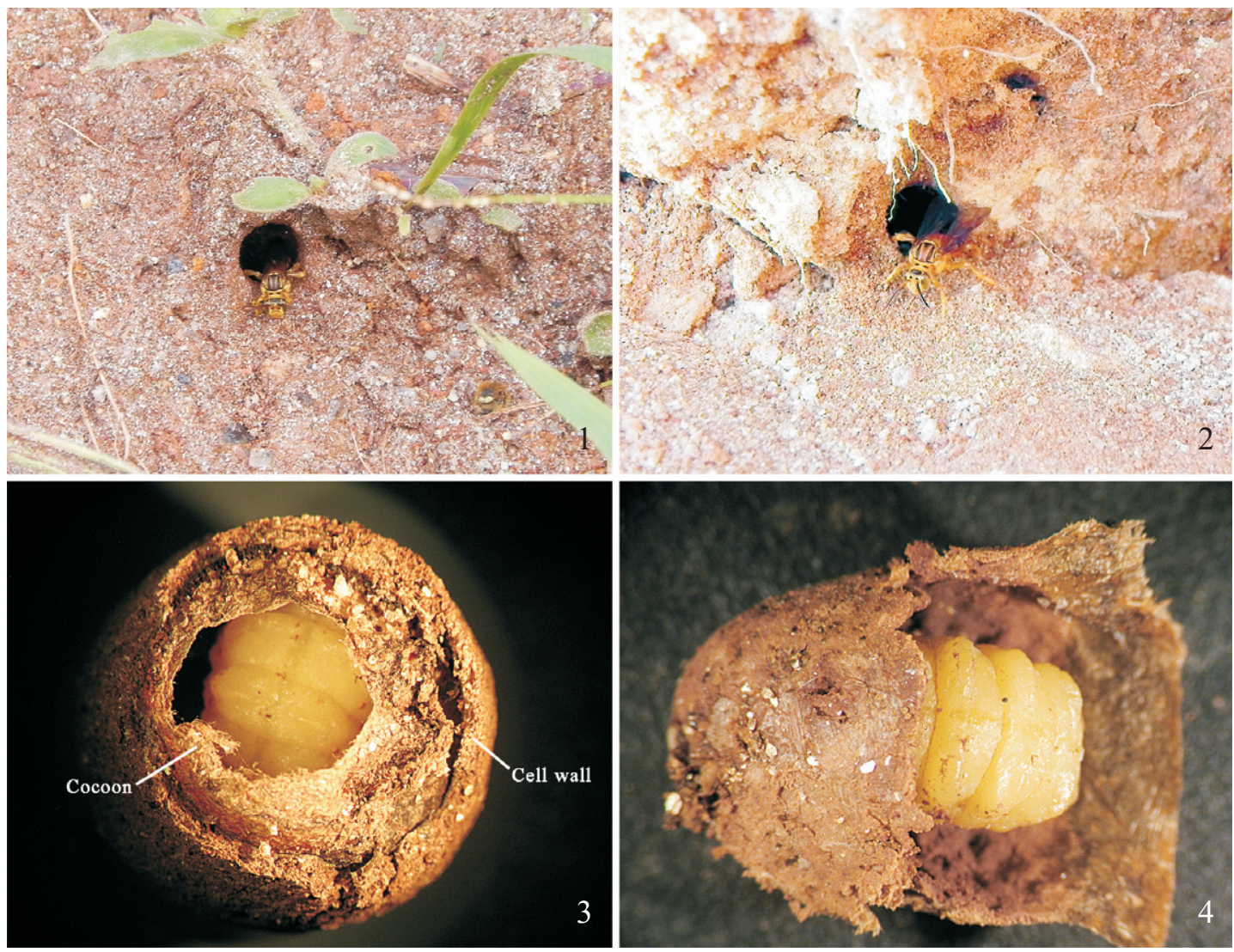

Figs. 1-4. Rhathymus friesei found parasitizing nests of Epicharis picta in Viçosa, Minas Gerais. 1-2, Adult females of R. friesei coming out of nests of E. picta. 3, Partly open host cell showing a mature larva of $R$. friesei within its cocoon. 4, Open cocoon partly showing a mature larva of $R$. friesei. 
Table I. Known host associations for cleptoparasitic bees of the tribe Rhathymini.

\begin{tabular}{|c|c|c|c|}
\hline Cleptoparasites & Hosts & Type of evidence ${ }^{1}$ & References \\
\hline Rhathymus ater (Smith, 1854) & Epicharis (Anepicharis) dejeanii Lepeletier, 1841 & Direct & Hiller \& Wittmann $(1994)^{2}$ \\
\hline \multirow[t]{3}{*}{ R. bicolor Lepeletier \& Serville, 1828} & Epicharis (Epicharana) rustica (Olivier, 1789) & Direct & Rozen (1969) \\
\hline & E. (Epicharis) bicolor Smith, 1854 & Indirect & Rocha-Filho et al. (2008) \\
\hline & E. (Epicharis) nigrita Friese, 1900 & Indirect & Gaglianone (2005) \\
\hline R. friesei Ducke, 1907 & Epicharis (Epicharoides) picta (Smith, 1874) & Direct & This study \\
\hline R. trinitatis Cockerell, 1935 & $\begin{array}{l}\text { Epicharis (Hoplepicharis) fasciata Lepeletier \& } \\
\text { Serville, } 1828\end{array}$ & Direct & Vesey-FitzGerald (1939); Rozen (1969) \\
\hline \multirow[t]{4}{*}{ R. unicolor (Smith, 1854) } & Epicharis (Anepicharis) dejeanii Lepeletier, $1841^{3}$ & Indirect & Raw $(1992)^{4}$ \\
\hline & E. (Epicharis) bicolor Smith, 1854 & Indirect & Rocha-Filho et al. (2008) \\
\hline & E. (Epicharis) nigrita Friese, 1900 & Indirect & Gaglianone $(2005)^{5}$ \\
\hline & Epicharis (Triepicharis) analis Lepeletier, 1841 & Indirect & Raw $(1991,1992)^{4}$ \\
\hline Rhathymus sp. & Epicharis (Epicharana) flava Friese, 1900 & Direct & Camargo et al. (1975) \\
\hline
\end{tabular}

1. Type of evidence: Direct, when larvae of the cleptoparasite have been reared from the host brood cells; Indirect, when only adult cleptoparasitic bees have been observed in the nesting areas of the putative host.

2. Cited as 'Rhathymus niger' nomen nudum and Rhathymus n. sp., but vouchers at DZUP correspond to $R$. ater.

3. Cited as Epicharis melanoxantha.

4. Cited as Rhathymus fulvus; however, specimens deposited in DZUP identified by A. Raw as R. fulvus correspond to R. unicolor.

5. Cited as Rhathymus sp., but voucher specimens examined by G. Melo correspond to $R$. unicolor

\section{ACKNOWLEDGMENTS}

The authors would like to thank technicians Íris Stanciola, Geraldo Paiva and Geraldo Ferreira, from the Apiary of the Universidade Federal de Viçosa, for their support during field work; Felipe Vivallo for preliminary identification of the host species; and CNPq for the financial support.

\section{REFERENCES}

Alves-dos-Santos, I; I. C. Machado \& M. C. Gaglianone. 2007. História natural das abelhas coletoras de óleo. Oecologia Brasiliensis 11: 544-557.

Camargo, J. M. F.; R. Zucchi \& S. F. Sakagami. 1975. Observations on the bionomics of Epicharis (Epicharana) rustica flava (Olivier) including notes on its parasite, Rhathymus sp. (Hymenoptera, Apoidea: Anthophoridae). Studia Entomologica 18: 313-340.

Engel, M. S.; C. D. Michener \& M. G. Rightmyer. 2004a. The cleptoparasitic bee tribe Rhathymini (Hymenoptera: Apidae): description of a new genus and a tribal review. Journal of Hymenoptera Research 13: 1-12.

Engel, M. S.; C. D. Michener \& M. G. Rightmyer. 2004b. A replacement name for the cleptoparasitic bee genus Rhathymodes (Hymenoptera: Apidae). Journal of Hymenoptera Research 13: 316.

Gaglianone, M. C. 2003. Abelhas da tribo Centridini na Estação Ecológica de Jataí (Luiz Antônio, SP): composição de espécies e interações com flores de Malpighiaceae, p. 279-284. In: G. A. R. Melo \& I. Alvesdos-Santos (Eds.). Apoidea Neotropica: Homenagem aos 90 Anos de Jesus Santiago Moure. Criciúma, Editora UNESC, 320 p.

Gaglianone, M. C. 2005. Nesting biology, seasonality and flower host of Epicharis nigrita (Friese, 1900) (Hymenoptera: Apidae: Centridini), with a comparative analysis for the genus. Studies on the Neotropical Fauna and Environment 40: 191-200.

Hiller, B. \& D. Wittmann. 1994. Seasonality, nesting biology and mating behavior of the oil-collecting bee Epicharis dejeanii (Anthophoridae, Centridini). Biociências 2: 107-124.
Michener, C. D. 2007. The Bees of the World. 2nd Edition, Baltimore, The Johns Hopkins University Press, 953 p.

Moure, J. S \& G. A. R. Melo. 2007. Rhathymini Lepeletier, 1841, p. 605608. In: J. S. Moure, D. Urban \& G. A. R. Melo (Orgs.). Catalogue of Bees (Hymenoptera: Apoidea) in the Neotropical region. Curitiba, Sociedade Brasileira de Entomologia, xiv+1058 p.

Raw, A. 1991. The circuitous trails used by males of the cuckoo bee, Rhathymus fulvus (Hym., Anthophoridae) in forest in Salvador, Brazil. The Entomologist 110: 110-113.

Raw, A. 1992. Mate searching and population size of two univoltine, solitary species of the bee genus Epicharis (Hymenoptera) in Brazil with records of threats to nesting populations. The Entomologist 111: 1-9.

Rocha-Filho, L. C.; C. I. Silva; M. C. Gaglianone \& S. C. Augusto. 2008. Nesting behavior and natural enemies of Epicharis (Epicharis) bicolor Smith 1854 (Hymenoptera Apidae). Tropical Zoology 21: $227-242$.

Rozen, J. G., Jr. 1969. The larvae of the Anthophoridae (Hymenoptera: Apoidea). Part 3. The Melectini, Ericrocidini, and Rhathymini. American Museum Novitates 2382: 1-24

Rozen, J. G., Jr. 1991. Evolution of cleptoparasitism in anthophorid bees as revealed by their mode of parasitism and first instars (Hymenoptera: Apoidea). American Museum Novitates 3029: 1-36.

Rozen, J. G., Jr. 2000. Systematic and geographic distributions of neotropical cleptoparasitic bees, with notes on their modes of parasitism, p. 204 210. In: M. M. G. Bitondi \& K. Hartfelder (Eds.). Anais do IV Encontro sobre Abelhas. Ribeirão Preto, Universidade de São Paulo, Faculdade de Filosofia, Ciências e Letras de Ribeirão Preto, 363 p.

Rozen, J. G., Jr. 2003. Eggs, ovariole numbers, and modes of parasitism of cleptoparasitic bees, with emphasis on neotropical species (Hymenoptera: Apoidea). American Museum Novitates 3413: 1-36.

Sigrist, M. R. \& M. Sazima. 2004. Pollination and reproductive biology of twelve species os Neotropical Malpighiaceae: stigma morphology and its implications for the breeding system. Annals of Botany 94: 33-41.

Vesey-FitzGerald, D. 1939. Observations on bees (Hym.: Apoidea) in Trinidad, B.W.I. Proceedings of the Royal Entomological Society of London (A) 14:107-110. 